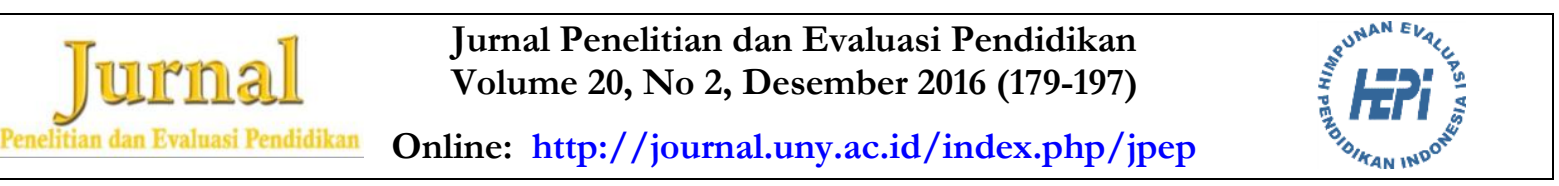

\title{
PARADIGMA PENDIDIKAN AGAMA DALAM MASYARAKAT PLURAL
}

\author{
Ju'subaidi ${ }^{*}$, Noeng Mubadjir ${ }^{2}$, Sumarno ${ }^{2}$ \\ ${ }^{1}$ STAIN Ponorogo, ${ }^{2}$ Universitas Negeri Yogyakarta \\ ${ }^{1}$ Jalan Pramuka, Ronowijayan, Siman, Kabupaten Ponorogo, Jawa Timur 63471, Indonesia \\ 2Jl. Colombo No. 1, Depok, Sleman 55281, Yogyakarta, Indonesia \\ * Corresponding Author. Email: subaidi_6@yahoo.com
}

\begin{abstract}
Abstrak
Penelitian ini bertujuan mengungkap paradigma yang mendasari pelaksanaan pendidikan agama di sekolah pluralistik, dan menghasilkan paradigma pendididikan agama yang lebih relevan dengan masyarakat Indonesia yang pluralistik. Desain penelitian ini adalah penelitian deskriptif eksploratif dengan menggunakan pendekatan kualitatif intepretif fenomenologi. Pengumpulan data dengan wawancara mendalam didukung dengan observasi dan dokumentasi. Analisis data menggunakan analisis interaktif yang meliputi reduksi data, display data dan kesimpulan. Di samping itu, juga menggunakan Interpretive Phenomenolgy Analysis. Hasil penelitian adalah Pelaksanaan pendidikan agama konvensional di sekolah yang pluralistik belum mengikuti Peraturan Pemerintah Nomor 55 Tahun 2007 dan PERMENAG Nomor 16 Tahun 2010 tentang Pengelolaan Pendidikan Agama pada Sekolah. Paradigma yang mendasari pendidikan agama adalah eksklusif dan inklusif. Paradigma pendidikan agama yang relevan dengan kondisi bangsa Indonesia yang pluralistik adalah paradigma budaya pluralisme demokratis-emansipatoris.
\end{abstract}

Kata kunci: paradigma, eksklusif, inklusif, konvensional, phenomenology, demokratis-emansipatoris

\section{THE PARADIGM OF RELIGION EDUCATION IN A PLURAL COMMUNITY}

\begin{abstract}
This study was to uncover the paradigm that became the basis of the implementation of conventional religion education in the pluralistic schools and to generate a religion education paradigm that would be more relevant to the pluralistic Indonesian society. The approach that the researcher employed in the study was the qualitative interpretative phenomenology. The data were collected through an in-depth interview, and the in-depth interview was supported by an observation and documentation. Then, for the data analysis the researcher implemented the interactive analysis that included data reduction, data display and conclusion. In addition, the researcher also implemented the Interpretive Phenomenology Analysis. The results of the study show that the implementation of conventional religion education in the pluralistic schools has not fulfilled the requirements of the Government Regulation Number 55 Year 2007 and the Minister of Religion Decree Number 16 Year 2010 about the Management of Religion Education in the School. The paradigm that becomes the basis of religion education is the exclusive and inclusive education. The religion education paradigm that is relevant to the conditions of pluralistic Indonesian society is the one which is democratic-emancipative, and pluralistic.
\end{abstract}

Keyword: paradigm, exclusive, inclusive, conventional, phenomenology, democratic-emancipatory

Permalink/DOI: bttp://dx.doi.org/10.21831/pep.v20i2.7256 


\section{Pendahuluan}

Indonesia merupakan negara yang multiagama dan etnis serta budaya, sehingga Indonesia menjadi negara yang kuat, tetapi tidak menutup kemungkinan sebagai trigger munculnya anarkisme yang disebabkan perbedaan pandangan dan praktik pendidikan khususnya pendidikan agama. Kondisi tersebut lebih disebabkan oleh rendahnya pemahaman masyarakat terhadap konsep pendidikan agama dan gagalnya internalisasi nilai-nilai pendidikan agama yang selama ini diperoleh melalui lembaga pendidikan. Di sinilah pentingya pendidikan agama, sebab pendidikan agama sebagai wahana paling efektif untuk menginternalisasikan nilai-nilai agama yang di dalamnya terdapat nilai demokrasi, pluralisme, toleransi, inklusivisme, dan lain sebagainya. Pendidikan agama pluralisme adalah model pendidikan yang menekankan pada nilai-nilai moral seperti kasih sayang, cinta-kasih, tolong menolong, toleransi, tenggang rasa, menghormati perbedaan, dan seluruh sikap-sikap yang mulia yang lain yang seharusnya dimiliki setiap orang.

Pluralitas agama di Indonesia merupakan realitas historis yang telah diakui oleh siapapun. Berdasar pada pluralitas tersebut, Indonesia mengambil format Negara Pancasila. Format negara Pancasila, negara tidak identik dengan agama tertentu/negara tidak melepaskan agama dari urusan negara. Ciri inilah yang menjadikan Indonesia sebagai varian 'sistem politik' yang ketiga di samping negara agama dan sekuler. Konsep 'Negara Pancasila' adalah menata secara kompromis dalam pola hubungan antara negara dan agama.

Dalam konteks dasar konstitusional model ini dapat dinyatakan bahwa tingkat kedekatan agama dan negara menjadi tergantung pada derajat religiositas para penyelenggara negara. Implikasi dari masing-masing politik tersebut dapat dilihat pada kebijakan negara yang terkait dengan kehidupan beragama dan para pemeluknya. Untuk kasus Indonesia tercermin pada kebijaksanaan negara yang berkaitan dengan pendidikan nasional dan pendidikan agama. Ada mutually reinforcing (saling memperkuat) antara pen- didikan yang dibangunnya dengan tatanan politik suatu negara (Kneller, 1993, p. 128). Dalam konteks Negara Indonesia pendapat tersebut secara inklusif terkait dengan penyelenggaraanpen didikan agama yang dilaksanakan oleh komunitas beragama di Indonesia. Hal ini dapat dilihat dari istilah politik pendidikan agama yang didefinisikan sebagai endapan dari politik negara, penjabaran dari tradisi bangsa dan nilai-nilai, serta sistem konsepsi rakyat mengenai bentuk negara dalam sistem pendidikan (Kartono, 1990, p. 28).

Pada aspek politik, pemerintah Indonesia tidak dapat mengabaikan sisi historis dari semangat religiositas, yang telah mengakar pada penyebaran agama melalui lembaga pendidikan dan pendidikan agama di lembaga-lembaga pendidikan formal. Religiositas dimaknai sebagai suatu sikap keteguhan pada keyakinan agama (Muhadjir, 2010, p. 3). Religiositas yang dimiliki seseorang hendaknya juga diikuti oleh spiritualitas. Spiritualitas dimaknai sebagai sikap pengakuan terhadap kebenaran transenden rasional objektif. Jika keyakinan agama (religiositas) tidak dibarengi dengan pemahaman spiritualitas, maka akan menjadi budaya pembenaran ajaran tanpa pertimbangan akal (dogmatic culture).

Secara historis, konsep sistem politik "Negara Pancasila" yang dibangun oleh pemerintah Indonesia menunjukkan perhatiannya terhadap keragaman etnis, budaya, dan agama. Pancasila sebagai suatu falsafah negara mengandung maksud memberikan dasar bagi perjuangan negara Indonesia yang dilahirkan atas dasar persatuan dan kemerdekaan yang berdaulat. Dengan kata lain, Pancasila sebagai sistem falsafah bangsa, telah menjadi alat pemersatu di samping menjadi syarat mutlak bagi kemerdekaan, dan sangat penting dalam upaya pembinaan bangsa Indonesia yang telah berdiri sejak 28 Oktober 1928, yang ditandai dengan ikrar "Sumpah pemuda". Upaya melestarikan nilai-nilai "Sumpah Pemuda", menyemangati para pemuda, dan bangsa Indonesia untuk tetap mempertahankan persatuan dan kesatuan dalam negara kesatuan Republik Inonesia, 
dipilihlah semboyan "Bhineka Tungal Ika". Bhineka di Indonesia berupa adanya berbagai kelompok etnis dengan berbagai ragam bahasa daerah (vernacular languages), dan beragam keyakinan agama. Konsep Bhineka sudah dikenal dan diakui sejak zaman kerajaan Majapahit; yang oleh Mpu Tantular ditampilkan konsep "Bhineka Tunggal Ika tan hana Dharma Mangrwa", beragam dengan satu Dharma tanpa tekad mendua (Tantular, 2009, p. 505). Keragaman yang ada diakui sebagai sebuah realitas, dan menjadi karakter dasar bangsa Indonesia yang memiliki toleransi dalam satu dharma tanpa ada niat untuk mendua dalam hati dan tindakan (baca. tidak munafik). Indonesia kendatipun Islam sebagai agama mayoritas tetapi agama minoritas tetapi diakui dan lindungi oleh negara. Dengan kata lain, bahwa pemerintah Indonesia yang menjadikan Pancasila sebagai falsafat hidup bangsa tetap mempertahankan kemajemukan bangsa dalam kesatuan (diversity in unity) sebagai sebuah keniscayaan dan menjadi modal guna melestarikan keutuhan bangsa dalam bingkai Negara Republik Indonesia yang berdaulat.

Sejalan dengan konsep tersebut, "Piagam Madinah" yang dikenal dengan "shulbu al-budaibiyah" dianggap sebagai dasar dari pembentukan negara Islam pertama di Madina, dan Nabi Muhammad saw. sebagai peletak dasar negara tersebut. Piagam Madinah tidak lain adalah suatu konstitusi yang merepresentasikan bahwa warga Madinah saat itu dapat dianggap telah membentuk satu kesatuan politik dan satu persekutuan yang diikat oleh perjanjian yang luhur diantara para warganya.

Dalam Piagam Madinah memuat suatu konsep kebebasan beragama yang dijamin oleh Islam sebagai agama mayoritas pada saat itu. Piagam ini juga mengatur adanya kebersamaan dalam bertanggung jawab terhadap negara (Kota Yatsrib) dari ancaman agresi luar (Haikal, 1990, p. 2002003). Komposisi masyarakat Madinah yang diakui dalam Piagam Madinah terdiri atas beberapa kelompok komunitas (plural), namun semua kelompok itu tunduk kepada sistem dan hukum Islam sebagai mayoritas.
Dalam mua'amalah dan uqubat (hukuman), orang-orang musyrik dan komunitas Yahudi semuanya tunduk kepada sistem dan hukum Islam. Dalam masalah akidah, ibadah, dan abwal asy-syakhsiyah, mereka diberi kebebasan dengan keyakinan masing-masing dan tidak dipaksa untuk mengikuti Islam. Mereka memiliki hak dan kewajiban yang sama dan adil tanpa ada diskriminasi.

Dengan demikian, konsep perlindungan kepada minoritas oleh mayoritas telah terjadi sejak zaman Rasulullah Muhammad saw, sebagaimana yang tertuang dalam "Piagam Madinah" dan pengakuan terhadap kemajemukan atau pluralitas juga telah ditampakkan pada zaman kerajaan Majapahit dengan semboyan yang ditulis oleh Mpu Tantular dalam Kitab Sutasoma, yakni "Bhineka Tunggal Ika Tan Hana Dharma Mangrwa".

Bagi bangsa Indonesia, pluralisme atau kemajemukan telah ada sejak permulaan abad ke 20 ketika terjadi kebangkitan nasional, dan kemajemukan menjadi isu yang menonjol. Nama Indonesia hakikatnya menunjukkan kemajemukan berupa banyak entitas budaya yang berbeda satu sama lain, ditambah dengan kemajemukan yang disebabkan oleh perbedaan agama dan keyakinan yang cukup banyak. Hal ini menunjukkan bahwa pluralisme (kemajemukan) mengandung kebenaran bagi bangsa Indonesia. Akan tetapi, pluralisme tidak dapat dan tidak boleh berdiri sendiri kalau Indonesia ingin hidup sepanjang zaman. Dalam pluralisme harus selalu ada paham kebersamaan tanpa paham kebersamaan, pluralisme dapat menimbulkan niat, gerak, dan usaha yang aneka ragam arahnya dan tujuannya.

Dalam konteks ke Indonesian, sistem politik pemeritahan Indonesia yang digagas oleh para pendiri negara (founding fathers) ini digali dari kehidupan bangsa pada zaman kerajaan Majapahit, dan sejalan dengan sistem pemerintahan Islam pada masa Rasulullah Muhammad saw. Dalam membangun kesatuan dan persatuan bangsa telah digunakan semboyan "Bhineka Tunggal Ika". Keragaman suku bangsa, budaya, agama, dan adat istiadat dipandang sebagai keka- 
yaan dan potensi untuk membangun bangsa dan negara yang kuat, maju, aman, adil, dan makmur. Sementara itu, tanggung jawab negara terhadap kehidupan beragama yang dianut oleh seluruh bangsa Indonesia dengan memberikan kebebasan beragama, beribadah, dan meningkatkan keyakinan dan ketakwaannya sesuai dengan agama dan keyakinannya. Sistem ini secara yuridisformal telah dijamin oleh undang-undang negera Republik Indonesia. Dengan demikian, bangsa Indonesia memiliki landasan konstitusional yang kuat untuk mengelola pluralitas secara baik dan benar. Landasan tersebut diperkuat oleh budaya bangsa Indonesia yang dikenal dengan sikap ramah, santun, saling menghormati, dan tolongmenolong. Di sisi lain, agama memandang keragaman suku bangsa dan budaya sebagai bagian dari sunnatullah dalam ciptaan-Nya. Sementara keyakinan teologis keagamaan dianggap sebagai tawaran yang bersifat persuasif. Artinya, boleh diterima atau ditolak dengan konsekuensinya masing-masing. Oleh karena itu, pluralitas harus dilihat dengan cara pandang yang positif dan disikapi dengan langkah-langkah yang konstruktif.

Agama memiliki tujuan untuk kemaslahatan umat manusia. Seiring dengan itu, agama sangat menghargai nilai-nilai kemanusiaan. Pertikaian antarkelompok keagamaan, bukan kesalahan ajaran agama tetapi lebih disebabkan oleh faktor-faktor keberagamaan, politik, ekonomi, dan faktor lain. Faktor keberagamaan yang dimaksud adalah intepretasi atau pemahaman terhadap teksteks keagamaan, strategi pengembangan agama, dan penyelenggaraan pendidikan agama.

Secara ideal, kebijakan Indonesia ke depan terhadap pluralitas agama mestinya lebih meningkat dibandingkan pada masa lalu dan sekarang. Teori Wirt maupun Garcia, tentang tipologi kebijaksanaan nasional terhadap kemajemukan di Amerika, yang dikenal dengan sebutan six theories of communal living. Wirt dan Garcia membedakan dua kelompok keyakinan, yaitu kelompok keyakinan dominan (KKD) dan kelompok keyakinan minoritas (KKM) (Saerozi, 2004, p. 13). Berdasarkan kategorisasi tersebut, Saerozi
(2004, p. 134) merumuskan model kebijaksanaan nasional akan agama menjadi empat; Pertama, adalah model dominasi, kedua, model penelantaran, ketiga model pluralisme agama, dan keempat model pluralisme agama konvensional.

Model pluralisme agama konvensional, yaitu negara (1) mengakui tiap-tiap kelompok keyakinan; (2) mendorong secara spesifik agar tiap-tiap kelompok mengamalkan nilai-nilai keimanan dan ketakwaan; (3) membina tiap-tiap individu di dalam kelompok keyakinan agar saling menghormati, dengan didorong oleh kedalaman iman masing-masing; (4) membuka akses partisipasi kepada kelompok keyakinan minoritas dalam pengambilan keputusan di tingkat masyarakat; dan (5) memberdayakan kelompok keyakinan minoritas yang tertindas (Saerozi, 2004, p. 15)

Penelitian Saerozi (2004) tentang Politik Pendidikan Agama dalam Era Pluralisme menemukan, pertama adalah kebijakan pendididkan agama di Indonesia memiliki pola konvensional, kedua berpola segresi fisik terhadap pemeluk agama, ketiga adalah berpola dominasi atas kelompok keyakinan minoritas, dan keempat pola pemberdayaan kelompok menoritas. Pola kebijakan yang terakhir menurutnya untuk menghindari terjadinya dominasi mayoritas atas minoritas dan penelantaran terhadap minoritas perlu pola kebijakan yang memberdayakan kelompok minoritas yang bersumber dari konsep pluralisme agama konvensional. Oleh karena itu, konteks penelitian ini adalah implementasi perlindungan mayoritas atas minoritas.

Dalam konteks implementasi dari konsep pendidikan agama konvensional tersebut diperlukan adanya kesamaan keyakinan antara guru agama, peserta didik dan kurikulumnya. Proses pendidikan agama model ini akan dapat menghindarkan praktik dominasi yang dilakukan oleh pihak lembaga pendidikan atau penelantaran sikap keagamaan para peserta didiknya disebabkan oleh tidak tersedianya guru agama.

Salah satu tujuan negara yang tercantum dalam pembukaan UUD 1945, terkandung suatu pengakuan bahwa negara me- 
miliki kewajiban-kewajiban terhadap keberadaan agama sebagai realitas kehidupan bangsa dan menjadi bagian pokok dari kesejahteraan warganya. Di antara kewajiban tersebut adalah pertama, memberikan perlindungan hukum bagi umat beragama; kedua, memberikan perlindungan keamanan bagi umat beragama; ketiga, membantu menyediakan fasilitas dan kemudahan bagi warganya untuk menjalankan agama masing-masing; keempat mendorong umat beragama dalam meningkatkan kualitas keimanan dan ketaqwaan; dan kelima, menjaga kerukunan hidup antar dan inter-umat beragama. Pemeliharaan cita-cita moral yang luhur dan budi pekerti sebagaimana dalam penjelasan UUD 1945 tentunya tidak dapat dilepaskan dari upaya pembinaan dan pengembangan kehidupan beragama yang salah satunya melalui pendidikan agama.

Pasal 33, Ayat 3 Undang-Undang Dasar 1945 menyatakan pemerintah mengusahakan dan menyelenggarakan satu sistem pendidikan nasional yang meningkatkan keimanan dan ketakwaan serta akhlak mulia dalam rangka mencerdaskan kehidupan bangsa, yang diatur dengan undang-undang. Upaya mewujudkan amanat undang-undang Dasar tersebut di atas pemerintah menyusun satu undang-undang yang mengatur penyelenggaraan pendidikan secara nasional bagi bangsa Indonesia, yaitu Undang-Undang Nomor 2 Tahun 1989 yang diperbaharui dengan Nomor 20 Tahun 2003 tentang Sistem Pendidikan Nasional.

Dalam konteks tanggung jawab terhadap eksistensi agama tersebut timbul kesadaran dan perhatian pemerintah Indonesia yang cukup tinggi terhadap pentingnya pendidikan agama. Hal itu menjadi dasar argumentatif untuk mendorong pendidikan agama menjadi salah satu mata pelajaran wajib di seluruh jalur, jenis, dan jenjang pendidikan formal. Signifikansi peran pendidikan agama telah diperkuat dengan penyelenggaraannya yang menggunakan pola pluralisme agama konvensional. Pola tersebut diartikan sebagai pendidikan agama yang bertujuan untuk menanamkan dan meningkatkan rasa keimanan dan ketakwaan dalam diri peserta didik terhadap suatu agama tertentu.

Pola penyelenggaraan pendidikan agama konvensional secara yuridis telah tercantum dalam Undang-Undang Nomor 20 Tahun 2003, tentang Sistem Pendidikan Nasional pada Pasal 12 Ayat 1 (a), "setiap peserta didik pada setiap satuan pendidikan berhak mendapatkan pendidikan agama sesuai dengan agama yang dianutnya dan diajarkan oleh pendidik yang seagama". $\mathrm{Na}$ mun, yang menjadi permasalahan adalah apakah setiap peserta didik telah memperoleh pendidikan agama yang memadai, sehingga upaya penanaman dan peningkatan kualitas keimanan dan ketakwaan peserta didik dapat meningkat sebagaimana yang telah diamanatkan oleh undang-undang tersebut.

Perangkat hukum yang menjadi dasar penyelenggaraan pendidikan agama cukup kuat yakni Peraturan Pemerintah Republik Indonesia Nomor 55 Tahun 2007 tentang Pendidikan Agama dan Pendidikan Keagamaan, sedangkan yang berkaitan dengan pengelolaan ada pada Peraturan Menteri Agama Republik Indonesia Nomor 16 Tahun 2010 tentang Pengelolaan Pendidikan Agama pada Sekolah. Sejalan dengan sejarah perkembangan pendidikan, pendidikan agama sebagai subsistem pendidikan nasional secara konseptual dan praktiknya yang sesuai dengan pola konvensional masih perlu terus dikaji sehingga menemukan paradigma yang lebih relevan dengan kondisi pluralitas bangsa Indonesia saat ini. Fenomena sosial tentang perilaku asusila dan asosial yang dilakukan para elitis dan sebagian warga sekolah serta berlangsungnya pendidikan agama di sekolah menunjukkan penerapan perilaku sosial dan kemanusiaan masih perlu dilakukan kajian ulang. Hal ini dapat dilihat dari berbgagi kasus pembunuhan, pemerkosaan, pelecehan seksual, korupsi, penyerangan terhadap sekolompok jamaat, pembakaran tempat ibadah dan perbuatan melawan hukum lainnya menunjukkan tingkat religiositas dan spiritualitas pelakunya masih rendah. Perilaku-perilaku tersebut diyakini merupakan dampak dari gagalnya internalisasi nilai-nilai 
agama yang diperoleh baik dari sekolah maupun lingkungan masyarakat.

Pertanyaanya adalah bagaimana pelaksanaan pendidikan agama di sekolah khususnya dalam meningkatkan keimanan dan ketakwaan peserta didik? Oleh karena itu, penyelenggaraan pendidikan agama di sekolah perlu dilakukan evaluasi secara komprehensif dan lebih mendalam, mengingat tujuan pendidikan adalah adanya perubahan kognitif, afektif, dan psikomotorik peserta didik sehingga terwujudnya manusia yang berkembang kemampuannya dalam memahami, menghayati, dan mengamalkan nilainilai agama dalam kehidupan individu maupun sosial.

Dengan demikian, penelitian ini akan diarahkan ke dalam konteks implementasi pendidikan agama konvensional yang berlangsung di sekolah. Sekolah yang dimaksud adalah sekolah yang memiliki keragaman agama, budaya dan etnis yang dianggap sebagai representasi masyarakat Indonesia yang pluralistik.

Penelitian ini mengambil tempat di SMAN 3 Madiun. Berdasarkan kajian awal peserta didiknya terdiri atas pemeluk agama yang diakui di Indonesia. Jumlah peserta didiknya tahun 2012 sebanyak 517 siswa meliputi Islam 85,02\%, Protestan 6,33\%, Katolik 5,18\%, Hindu 1,54\%, Buddha 1,54\%. Etnisnya terdiri atas etnis Jawa dan China. Hal ini peneliti dianggap sebagai representasi sekolah yang pluralistik. Sekolah tersebut merupakan salah satu sekolah yang pertama pada tahun 2006 telah menjadi Rintisan Sekolah Bertarap Internasional (RSBI). Pengajaran dan pengembangan kurikulum menggabungkan keunggulan akademik, afektif maupun psikomotorik dan menjadi $A n$ IT advanced integreted schoool. Pengembangan sekolah bertarap internasional diperuntukkan bagi masyarakat ekonomi lemah hingga tinggi. Komitmennya terhadap kepedulian masyarakat berekonomi lemah dan kesetaraan gender ditunjukkan dalam penerimaan peserta didik masing-masing sebesar $10 \%$ dari total peserta didik. Hal ini dilakukan untuk menetralisir kesan masyarakat terhadap SMAN 3 Madiun hanya menerima para peserta didik dari kalangan atas. Dengan sejumlah prestasi dan reputasinya diyakin telah memiliki sumberdaya yang qualified dan kompeten dan manajemen terstandar.

Berdasarkan kajian awal tersebut, penelitian ini bertujuan untuk mengungkap paradigma yang mendasari pelaksanaan pendidikan agama di sekolah pluralistik, dan menghasilkan paradigma pendididikan agama yang lebih relevan dengan masyarakat Indonesia yang pluralistik dengan mengarahkannya pada implementasi pendidikan agama konvensional (agama Kristen, Katolik, Buddha, Islam, Hindu, Konghuchu) dan paradigma pelaksanaan pendidikan agama di Sekolah.

\section{Metode Penelitian}

Penelitian ini menggunakan pendekatan kualitatif interpretatif Phenomenologik dengan paradigma naturalisltik. Pendekatan ini dipilih secara filosofis sesuai dengan karakter data, teknik pengumpulan data dan analisis data yang digunakan. Penelitian ini juga mengacu pada pendekatan post positivisme-phenomenologi (Muhadjir, 2001, p. 17), karena berusaha mengungkap dan menjelaskan berbagai fenomena pelaksanan pendidikan agama konvensional, paradigma pelaksanaan pendidikan agama, dan menawarkan paradigma baru yang lebih relevan dengan konteks masyarakat Indonesia.

Pemilihan pendekatan ini didasarkan atas sifat kajian, perspektif teoretik, sasaran maupun data penelitian yang diyakini lebih relevan dengan pendekatan kualitatif-phenomenologi. Kualitatif intepretif phenomenologik mendasarkan pada filsafat phenomenologik, yang mengakui adanya peran subjek saat mengamati fakta, saat menganalisis, dan saat memaknai fakta di luar diri maupun dalam diri subjek yang bersangkutan; dan juga saat berteori (Muhadjir 2011, p. 510). Hors menyatakan, melalui pendekatan alamiah akan diperoleh pemahaman dan penafsiran secara relatif mendalam mengenai makna dari kenyataan dan fakta yang relevan (Guba \& Lincoln, 1985, p. 35). Penelitian kualitatif adalah penelitian yang datanya berupa data kualitatif, yaitu descriptive material, 
yang meliputi catatan, data verbal seperti apa yang dikatakan orang dalam wawancara, data visual seperti gambar/foto (Wilson, 1995 , p. 8). Dengan demikian, penggunaan pendekatan kualitatif fenomenologi didasarkan pada asumsi bahwa hal-hal yang menyangkut pemikiran dan keaslian sebuah kegiatan pendidikan agama tampaknya hanya dapat diungkap secara jelas dan mendalam dengan pendekatan tersebut.

Jika didasarkan pada kriteria pengelompokan penelitian pendidikan maka penelitian ini masuk kategori descriptive research, yaitu berusaha mengungkap apa yang terjadi pada pelaksanaan pendidikan agama dan pemikiran yang mendasarinya (Best, 1997, p. 15). Desain penelitian yang menggunakan pendekatan kualitatif lebih bersifat umum tidak rinci, fleksibel, dan dapat berkembang sesuai dengan situasi sosial (people, peper, activities). Melalui pendekatan tersebut akan terungkap meliputi persepsi, pemikiran, kemauan dan keyakinan subjek tentang sesuatu di luar subjek ada sesuatu yang transenden di samping yang a-posteriori. Di sisi lain juga akan terungkap fenomena empirik sensual dari subjek penelitian yang lebih banyak membicarakan gejala-gejala subjek suatu kelompok masyarakat yang menjadi objek penelitian (Muhadjir, 1990, p. 27). Penelitian yang bersifat abstrak berusaha mengungkap pengakuan dan keyakinan sekaligus menganggap penting dan berharga terhadap yang transenden. Hal yang demikian tidak mungkin dilakukan dan didekati melalui penelitian kuantitatif-positivistik.

Di dalam masyarakat plural terdapat kesamaan teologis pada level struktural dan berbeda pada level ideologis (Waldman, 1985, p. 92), maka penelitian ini juga menggunakan pendekatan teologis. Pendekatan ini dimaksudkan sebagai interprestasi terhadap berbagai ide yang saling berkaitan dalam masyarakat plural, yakni ide-ide yang merefleksikan kepentingan dan komitmen moral serta sosial. Pendekatan semacam ini menjelaskan dan menilai kondisi sosial, peran individu dalam masyarakat yang diteliti serta implikasi nyata dari aksi sosial. Pendekatan ini juga mengasumsikan bahwa elemen-elemen ideologi diterima sebagai formulasi filosofis bersifat tentatif sesuai dengan perubahan sosial-budaya (Jaenuri, 2002, p. 8).

Penelitian ini dikategorikan ke dalam penelitian kualitatif karena bersifat alamiyah, peneliti sebagai instrumen kunci, berusaha mengungkap dunia makna dibalik tindakan seseorang (Bogdan \& Biklen, 1998, pp. 4-7) dan diharapkan mampu memberikan penjelasan secara mendalam (verstehen) tentang pemikiran pendidikan agama dalam sekolah pluralistik di Kota Madiun. Setelah diperoleh deskripsi dan kesimpulan atas berbagai fenomena terkait dengan realitas pelaksanaan pendidikan agama konvensional di sekolah, langkah selanjutnya adalah merumuskan paradigma pendidikan agama yang dibangun dari grass root. Salah satu manfaat yang diharapkan dari penelitian ini adalah sumbangan/konstribusi bagi perbaikan pendidikan agama di Sekolah yang sesuai dengan konteks masyarakat plural (ke-Indonesiaan).

Secara metodologis pendekatan yang dipilih adalah model social action. Model ini, peneliti melibatkan diri langsung dan menyatu dengan subjek penelitian dalam berbagai aktivitas pendidikan agama di sekolah (partisipasi aktif). Tujuan keterlibatan ini tidak sekedar untuk memahami ragam fenomena dan persepsi grass root dengan menggunakan intepretasi atas fakta dengan model etik dan emik saja, tetapi juga menggunakan logik-neotik. Dengan langkah ini diharapkan dapat diungkap dan dirumuskan fakta tak terkatakan dari responden (nature of reality) untuk selanjutnya diarahkan dan difasilitasi ke arah pemikiran sesuai konsep atau model paradigma pendidikan agama konvensional yang ditawarkan. Model Discourses Foucouldian juga digunakan untuk mengarahkan lebih lanjut pemahaman subjek penelitian (grass root) akan pentingnya pendidikan agama yang berkualitas dalam kehidupan masyarakat yang memiliki keunggulan komparatif dan kompetitif. Tujuannya mengintervensi pemikiran dan pemahaman grass-root agar berubah ke arah pemikiran dan pemahaman yang proporsional dan lebih maju tentang eksistensi pendidikan agama sesuai dengan 
pola pendidikan agama konvensional. Secara teknis proses ini dilakukan melalui pemberian text reading dan diskusi dengan kelompok guru agama. Untuk mengetahui dan mengukur pemahaman grass-root atas konsep atau model yang ditawarkan, dilakukan komunikasi interaktif dan diskusi dengan guru agama. Dengan teknik ini diharapkan ide dan gagasan yang diajukan oleh peneliti dapat terdeseminasikan.

Proses pengembangan melalui dua tahap, pertama studi pendahuluan meliputi, pengumpulan data, pemaknaan fenomena; deskripsi; kategorisasi rumusan \& spesifikasi kesimpulan (rumusan verbal) dan kedua pengembangan meliputi perumusan dan diseminasi model paradigma pendidikan agama konvensional. Produk yang dihasilkan terbatas sampai pada konseptualisasi paradigma pendidikan agama konvensional.

Wawancara mendalam (indept-interview) dilakukan dengan mengajukan beberapa pertanyaan secara mendalam kepada 6 orang guru pendidikan agama dan kepala sekolah yang berhubungan dengan pengelolaan dan pelaksanaan pendidikan agama serta pandangan terhadap peran pendidikan agama ke depan. Observasi digunakan untuk mengetahui bagaimana para guru agama melakukan pembelajaran dan mengetahui upaya pembudayaan nilai-nilai agama di lingkungan sekolah. Teknik dokumentasi digunakan untuk mengetahui perangkat pembelajaran ygn dibuat.

Validasi keakurasian temuan dengan triangulasi sumber dan peer debriefing. Sedangkan Pemaknaan terhadap berbagai peristiwa dilakukan melalui analisis data. Analisis data menggunakan analisis data interaktif yang diintrodusir oleh Miles and Huberman, meliputi pengumpulan data, reduksi data, display data, dan kesimpulan dan Interpretive Phenomenolgy Analysis.

\section{Hasil Penelitian dan Pembahasan}

Pendidikan agama sebagai subsistem pendidikan nasional memiliki nilai penting dan strategis dalam membangun masyarakat yang madani dan berkeadaban. Hal ini menjadi ciri khas bangsa Indonesia dan menjadi tujuan pendidikan nasional. Pendidikan agama sebagai wahana paling efektif untuk menginternalisasikan nilai-nilai pendidikan agama karena di dalam nilai-nilai agama terkandung nilai demokrasi, toleransi, inklusivisme, menghormati perbedaan, dan nilainilai moral yang lain. Oleh karena itu, menjadi penting untuk melihat kembali pelaksanaan pendidikan agama di sekolah khususnya sekolah-sekolah yang memiliki keragaman budaya, agama, etnis.

\section{Pelaksanaan Pembelajaran Pendidikan} Agama Konvensional

Pada tahun 2012 jumlah peserta didik 517 yang terdiri atas pemeluk agama Islam sebesar 88,95\%, agama Kristen 5\%, agama Katollik 4,85\%, agama Hindu 0,2\%, dan agama Buddha 0,8\%. Sejumlah peserta didik tersebut diasuh oleh 6 orang guru agama, yaitu 2 orang guru agama Islam, seorang guru agama Kristen, seorang guru agama Katolik, seorang guru agama Buddha, dan seorang guru agama Hindu. Status lima orang guru agama sebagai guru tatap (PNS) di SMAN 3 Madiun dan satu guru agama Budha berstatus honorer. Dari enam guru agama yang telah memiliki sertifikat pendidik hanya tiga orang guru, yaitu 2 orang guru agama Islam dan seorang guru agama Kristen, sementara yang lain belum bersertifikat pendidik. Artinya, tiga orang guru belum diakui sebagai pendidik profesional. Tiga guru yang telah tersertifikasi masih menunjukan kurang memiliki kompetensi secara optimal yang dipersyaratkan oleh standar pendidik dan tenaga kependidikan. Seharusnya yang telah bersertifikat pendidik telah memenuhi kualifikasi dan kompetensi.

Implementasi pendidikan agama konvensional pada sekolah diperlukan adanya kesamaan keyakinan antara guru agama, peserta didik, dan kurikulumnya. Hal ini diharapkan terhindar dari praktik dominasi oleh pihak institusi atau penelantaran peserta didiknya untuk memperoleh hak pendidikan agama. Di sisi lain, implementasinya juga harus mampu mendorong setiap individu peserta didik untuk meningkatkan keimanan dan mengamalkannya dengan penuh kesadaran dengan didorong oleh kedalaman iman dan 
ketakwaannya, serta memberdayakan diri dari hegemoni kekuasaan. Pembahasan selanjutnya tentang sarana prasarana, pembelajaran intrakurikuler dan ekstrakurikuler, dan penilaian hasil belajar agama.

\section{Sarana dan Prasarana}

Untuk menunjang proses pembelajaran pendidikan agama, SMAN 3 telah menyediakan beberapa sarana prasarana berupa ruang proses belajar mengajar, ruang perpustakaan dan tempat ibadah. Pembelajaran pendidikan agama Islam berlangsung di setiap kelas. Pendidikan agama Kristen, Katolik, dan Hindu disediakan masing-masing satu ruang. Dari ruangan yang tersedia bagi pendidikan agama Islam, Kristen, Katolik telah memenuhi standar sarana dan prasarana, sedangkan ruang untuk pendidikan agama Hindu kurang baik dan terkesan seadanya dan bekas gudang, ukurannya $3 \mathrm{x}$ $3 \mathrm{~m}$, tidak dilengkapi dengan media pembelajaran. Di dalam ruang berisi sebuah meja tulis, 4 buah kursi lipat yang kondisinya rusak kecuali dua buah untuk guru dan siswa. Sarana pembelajaran ataupun sarana ibadah pendidikan agama Buddha belum tersedia, sehingga pembelajaran agama Buddha dilakukan secara gabungan dengan para peserta didik agama Buddha dari sekolah-sekolah lain dan pelaksanaan di Klenteng Madiun. Sarana ibadah yang tersedia sebuah masjid, sedangkan sumber belajar pendidikan agama dalam bentuk buku pegangan peserta didik dan pendidik/guru serta sejenisnya telah tersedia di perpustakaan. Buku pegangan guru terdiri atas 2 buah judul dengan jumlah delapan eksemplar. Buku teks siswa sebanyak dua puluh (20) judul dan berjumlah 708 eksemplar, sedangkan buku penunjangnya sebanyak tujuh belas (17) judul dan berjumlah 196 eksemplar (Nurmilati, 20112012, p.3).

Memperhatikan sarana dan prasarana dapat dinyatakan bahwa penyediaan ruang belajar dan ruang ibadah belum memenuhi standar sarana dan prasarana, sedangkan penyediaan sumber belajar dalam bentuk buku telah mencukupi, akan tetapi pemanfaatan sebagai sumber belajar belum maksimal. Hal ini ditunjukkan pada setiap pembelajaran satu buku untuk dua siswa. Menurut peneliti, kondisi ini disebabkan oleh anjuran guru untuk menggunakan sumber belajar tersebut kurang optimal. Standar yang ditetapkan rasio buku dengan peserta didik 1:1. Di sisi lain laboratorium pendidikan agama sebagaimana yang disyaratkan peraturan menteri agama juga belum tersedia.

\section{Pembelajaran Intrakurikuler}

Upaya memenuhi standar proses yang disyaratkan dalam standar nasional pendidikan guru pendidikan agama SMAN $3 \mathrm{Ma}-$ diun telah melakukan perencanaan proses pembelajaran, pelaksanaan proses pembelajaran dan penilaian hasil pembelajaran. Dalam perencanaan, para guru agama sebagaimana lazimnya sebagai pendidik yang profesional telah menyusun perencanaan proses pembelajaran. Berdasarkan dokumen RPP yang telah dibuat oleh para guru agama secara adminstratif telah dipenuhi, akan tetapi secara substansial masih terdapat beberapa komponen RPP yang belum dikembangkan secara optimal, misalnya sebagian kompetensi dasar, materi, penilaian. Kurikulum Tingkat Satuan Pendidikan memberi peluang seluas-luasnya kepada guru untuk mengembangkannya. Hal ini disebabkan kemampuan guru dalam mengembangkannya terbatas dan pembinaan oleh pengawas kurang optimal. Kehadiran pengawas di sekolah terbatas pembinaan terhadap pemenuhan administrasi. Kegiatan dalam Musyawarah Guru Mata Pelajaran kurang dimanfaatkan untuk meningkatkan kompetensi profesional.

Berkaitan dengan pelaksanaan proses pembelajaran, guru agama belum maksimal melakukannya. Artinya proses pembelajaran menunjukkan pada pembelajaran yang kurang sesuai dengan perencanaan yang dibuatnya sendiri. Proses pembelajaran di kelas seringkali tidak sesuai dengan yang telah ada di dokumen rencana pelaksanaan pembelajaran, misalnya kebanyakan guru agama melakukan pembelajaran tanpa kegiatan awal yang sebenarnya penting untuk dilalui agar peserta didik mengetahui akan tujuan pembelajaran dan mengaktifkan mereka dalam 
mengikuti pembelajaran. Kebanyakan guru langsung kegiatan inti dan penutup. Metode mengajar kurang bervariasi bahkan cenderung menggunakan single methode dan metode ceramah paling sering digunakan. Penggunaan metode diskusi kurang konsisten $\mathrm{pa}$ da langkah-langkahnya. Penyampaian materi lebih bersifat eksklusif-doktrinis, dan pembahasan materi dengan pendekatan leteralscriptural artinya apa yang diperoleh dari teks baik dari buku maupun kitab disampaikan tanpa melalui proses berpikir. Model pembelajaran seperti ini diyakini akan membosankan dan tidak terjadi proses pengembangan budaya baca tulis dan berpikir kritis.

Penilaian merupakan unsur yang penting dari proses pembelajaran. Ketercapaian tujuan pembelajaran dapat dilihat dari hasil penilaian. Kualitas pembelajaran dengan kualitas penilaian merupakan dua hal yang tak dapat dipisahkan. Pembelajaran yang baik akan menghasilkan kualitas belajar yang baik, sedangkan mutu pembelajaran hanya akan dapat dilihat dari hasil penilaiannya. Sistem penilaian yang baik akan mampu memberikan motivasi belajar peserta didik yang lebih baik.

Dalam hal penilaian, para guru agama di SMAN 3 Madiun masih belum semua memahami secara benar prosedur penyusunan instrumen, masih terjadi overlapping, yang seharusnya indikator diukur dengan tes pilihan ganda, justru guru menggunakan bentuk uraian objektif. Guru agama dalam menyusun instrumen penilaian uraian juga belum dilengkapi dengan rubrik dan pedoman penskoran. Penyusunan intrumen tes pada tengah maupun akhir semester didasarkan pada jumlah skor keseluruhan yang telah disepakati. Misalnya, soal dibuat dengan komposisi pilihan ganda 60 dan bentuk uraian jumlah sekor maksimal 40. Guru agama tidak pernah melakukan pengembangan instrumen (tes) yang sesuai dengan langkahlangkah pengembangan instrumen. Hal ini mengindikasikan bahwa instrumen yang disusun tidak pernah dilakukan uji coba dan dilakukan analisis baik validitas maupun reliabilitasnya. Kondisi ini menunjukkan bahwa para guru agama belum memiliki kemampuan untuk mengembangkan instrumen tes, dampaknya akan merugikan para peserta didik dan mereduksi fungsi alat ukur itu sendiri.

\section{Pembelajaran Ekstrakurikuler}

Proses pembelajaran ekstrakurikuler merupakan suatu kegiatan pembelajaran yang berlangsung di luar pembelajaran intrakurikuler. Bentuk pembelajaran ektrakurikuler adalah berbagai kegiatan yang berfungsi sebagai pendalaman yang merupakan pengayaan, penguatan yang merupakan upaya pemantapan keimanan dan ketakwaan, pembiasaan diarahkan pada upaya terwujudnya pengamalan dan pembudayaan ajaran agama serta perilaku akhlak mulia dalam kehidupan sehari-hari.

Pembelajaran ekstrakurikuler pendidikan agama secara normatif meliputi fungsi pengayaan (pemberian tugas tambahan dari materi intrakurikuler), penguatan (melalui pengamalan ajaran), pembiasaan (melalui pengamalan dan pembudayaan). Pelaksanaan pembelajaran ekstrakurikuler berbentuk tatap muka atau nontatap muka. Bentuk lain pembelajaran ekstrakurikuler ini adalah perluasan dan pengembangan. Proses pembelajaran ekstrakurikuler pendidikan agama di SMAN 3 Madiun sesuai dengan agama yang dianut siswanya.

Pendidikan agama Islam dalam pembelajaran ekstrakurikulernya pada aspek pengayaan melalui pemberian tugas tambahan atas materi pembelajaran intrakurikuler, aspek penguatan dilakukan melalui pengamalan ajaran Islam, baik yang sunnah mapun yang wajib, sedangkan pembiasaan dilakukan melalui pengalaman dan pembudayaan berbentuk berjabat tangan dengan para guru dan karyawan serta antarteman, menggunakan bahasa jawa dalam berkomunikasi di setiap hari Jumat, mengadakan kegiatan Peringatan Hari-hari besar Islam dan melakukan kunjungan ke panti asuhan yang bersifat temporal. Pendalaman melalui kegiatan kajian Islam dengan kerja sama dengan "alKahfi" dan bersifat sukarela. Pada aspek perluasan dan pengembangan melalui mendalami seni baca Alqur'an. 
Pendidikan agama Kristen bentuk kegiatan pembelajaran ekstrakurikuler dalam rangka pendalaman yaitu kegiatan belajar mengajar bersifat pengayaan dan hanya pda materi-materi tertentu. Penguatan iman dan takwa peserta didik yang dilakukan oleh guru agama Kristen berbentuk ibadah, retreat dan pendalaman alkitab, sedangkan peningkatan keimanan dan ketakwaan mereka dilakukan dengan mengkaji 'al-Kitab' secara mendalam dan berdoa bersama baik di gereja maupun di tempat lain pada setiap hari Jumat. Upaya memberikan pengalaman dan pembudayaan berperilaku baik melalui kunjungan ke panti asuhan, dan dilakukan bersamaan dengan hari paskah.

Kegiatan pembelajaran ekstrakurikuler pendidikan agama Katolik berbentuk tatap muka. Pengayaan dan pendalaman dilakukan dari hasil ulangan formatif atau sumatif, dilakukan dengan memberi materi tambahan. Pembiasaan, pengamalan dan pembudayaan dilakukan dalam bentuk kunjungan ke panti asuhan dan pemberian keteladanan berdisiplin, ajakan dan nasihat yang baik. Penanaman dan peningkatan keimanan melalui kegiatan retreat, rekoleksi. Pendalaman iman adalah bukan wewenang guru agama, tetapi kewenangan sepenuhnya pihak gereja.

Kegiatan pembelajaran ekstrakurikuler pendidikan agama Hindu, merupakan upaya pendalaman, penguatan iman dan ketakwaan, pembiasaan, perluasan dan pengembangan. Upaya pendalaman dengan cara pemberian tambahan materi yang lebih tinggi dari apa yang telah dibahas dan dilakukan di sekolah. Kegiatan penguatan iman dan ketakwaan melalui praktik sembahyang dan meditasi secara rutin.

Pembelajaran ekstrakurikuler pendidikan agama Buddha dilakukan melalui tatap muka dan mengambil tempat di TITD Hwi Ing Kiong (Klenteng Madiun). Pembelajaran ekstrakurikuler agama Hindu merupakan upaya pendalaman dalam bentuk pengayaan, penguatan terhadap keimanan dan ketakwaan. Pembiasaan melalui pengamalan dan pembudayaan dalam kehidupan sehari-hari baik di sekolah maupun di rumah masing-masing peserta didik. Kegiatan pengayaan ini dilakukan di tengah dan atau akhir semester. Pengayaan berbentuk latihan meditasi dan pendalaman terhadap Dhamma Pala.

Memperhatikan data tersebut, masih terdapat perbedaan persepsi terhadap kegiatan ekstrakurikuler pendidikan agama. Pengayaan yang seharusnya dipahami dengan memberikan tambahan materi terhadap materi intrakurikuler dan dilaksankan diluar jam intrakurikuler. Pada kasus pendidikan agama Katolik pendalaman iman bukan wewenang guru agama tetapi gereja, yang menjadi persoalan justru masing-masing gereja memiliki cara yang berbeda-beda. Di sisi lain kehadiran ke geraja bagi orang Katolik hanya sekali dalam seminggu. Jika demikian, maka pendalaman iman dirasa sulit untuk diwujudka. Dalam hal perluasan dan pengembangan dari kelima agama, hanya agama Islam yang melakukan upaya pengembangan dan perluasan. Dengan demikian, upaya pendalaman terhadap materi intrakurikuler tidak akan tercapai tujuannya.

Penilaian hasil belajar pendidikan agama melalui ujian hanya berlaku pada pendidikan agama Islam, sedangkan agama nonIslam tidak ada ujian praktik. Hal ini disebabkan oleh tidak adanya materi praktek dalam pembelajaran agama-agama non-Islam.

Penilaian hasil belajar oleh pemerintah hanya berlaku untuk pendidikan agama Islam dalam bentuk UASBN dan secara teknis dikelola oleh subdit pendidikan dan madrasah (Penma) Kementerian agama kota Madiun sebagai pelaksana di daerah. Pelaksanaan UASBN secara teknis menimbulkan kendala yakni pada aspek distribusi. Persoalan lain yang timbul adanya UASBN hanya agama Islam adalah sikap diskriminasi terhadap pendidikan agama selain Islam. Pembelajaran agama non-Islam tidak terukur secara nasional serta secara ekonomi mengurangi pendapatan para guru agamanya.

\section{Problematika Pendidikan Agama Konvensional}

Terdapat dua hal dalam pengelolaan pendidikan agama konvensional, yaitu kurikulum, dan sumber daya manusia. 
Pengembangan Kurikulum di SMAN 3 Madiun tidak dilakukan bersama komite sekolah. Hal ini tidak mengikuti prinsip pengembangan kurikulum. Keterlibatan komite sekolah dalam pengembangan kurikulum diharapkan dapat memberikan masukan-masukan tentang kebutuhan lingkungan masyarakat yaitu para wali murid untuk mendukung tercapainya kompetensi lulusan. Jika pengembangan kurikulum tidak sinergi dan tidak relevan dengan kepentingan masyarakat, maka peserta didik tidak akan memiliki keterampilan sosial (social skill) sebagai bekal hidup bermasyarakat yang luas. Dampak lebih jauh adalah sekolah hanya akan menghasilkan lulusan yang tidak dinginkan masyarakat sehingga menambah jumlah pengangguran yang akhirnya menjadi beban negara.

Problem yang berkaitan dengan kurikulum adalah adanya cara berfikir dikotomis antara pendidikan agama dengan pendidikan umum. Cara berpikir yang membedakan pendidikan agama dan pendididkan umum terkesan tidak dapat dipertemukan. Kurikulum 2013 yang secara konseptual diupayakan ke arah integrasi nilai spiritual yang bersumber dari nilai agama ke dalam mata pelajaran umum ditingkat pendidik juga masih menjadi problem. Kesulitan melakukan penilaian aspek spiritual terletak pada belum dimilikinya pemahaman konseptualisasinya dan teknik implementasinya mengingat jumlah peserta didik yang banyak.

Standar Isi dan Kom-petensi Dasar yang tertuang dalam lampiran Standar Isi pada Permendikbud Nomor 64 Tahun 2013 menunjukkan perbedaan besarnya muatan materi ajar antarpendidikan agama dan rasio jam pelajaran yang kurang memadai. Akibat dari pemahaman tersebut di sekolah umum (bukan sekolah bercirikan agama) muncul dua fenomena. Pertama, pembelajaran pendidikan agama masih bersifat literal-scriptural. Pembelajaran model ini masih mementingkan apa yang ada di dalam teks kitab suci tanpa adanya upaya mengontekstualisasi dengan kehidupan para peserta didik. Hal ini seringkali menimbulkan sikap eksklusif. Kedua, pembelajaran pendidikan agama se- cara metodologis juga masih terdominasi oleh indoktrinasi-dogmatis. Dengan kata lain, bahwa penyampaian materi agama oleh kebanyakan guru agama belum mampu mengembangkan potensi berpikir kritis, sehingga penerimaan peserta didik terhadap ajaran agama baru pada kesadaran magis (magical consciousness) belum sampai pada kesadaran kritis (critical consciousness). Kesadaran magis merupakan sikap peserta didik secara dogmati menerima sesuatu (mis. ajaran agama) dari guru tanpa adanya mekanisme memahami makna dari konsep yang diterima (Fakih, 2008, p. xvi). Dengan kata lain, peserta didik hanya mengikuti apa yang dikatakan guru tanpa melalui pemikiran rasional. Oleh karena itu, pembelajaran pendidikan agama seharusnya mampu merubah peserta didik dari kesadaran magis kepada kesadaran kritis.

Problematika kurikulum kedua adalah pemahaman guru agama terhadap regulasi pendidikan agama yang kurang menjadi kendala tersendiri dalam mengembangkan kurikulum pendidikan agama. Para guru agama pada tahun 2012 belum mengetahui kalau ada Peraturan Menteri Agama (Permenag) Nomor 16 Tahun 2010 tentang Pengelolaan Pendidikan Agama pada Sekolah. Hal ini lebih disebabkan oleh kurangnya sosialisasi regulasi yang menyangkut penyelenggaraan pendidikan agama pada sekolah dari Kementerian Agama. Minimnya pembinaan pengawas agama menyebabkan rendahnya pemahaman terhadap regulasi.

Dari uraian tersebut dapat disimpulkan bahwa problem yang terkait dengan kurikulum pendidikan agama konvensional adalah; (a) pengembangan kurikulum yang disusun oleh satuan pendidikan menunjukkan kurangnya pemahaman para pengembang kurikulum terhadap regulasi yang berkaitan dengan penyelenggaraan pendidikan dan prinsip-prinsip pengembangan kurikulum, (b) pada tataran implementasi kurikulum dihadapkan pada persoalan sumberdaya manusia dalam hal ini tenaga pendidikan dan kependidikan yang masih belum memiliki pandangan yang sama dan respon yang memadai oleh warga sekolah terhadap pe- 
laksanaan pendidikan agama. Di sisi lain, kompetensi profesional khususnya guru agama masih memerlukan pembinaan dan peningkatan, jika tidak maka pembelajaran pendidikan agama akan menjadi sesuatu yang tidak menarik dan membosankan, (c) kerja sama instansi terkait dalam hal ini sekolah dengan Kementerian Agama masih menunjukkan intensitas rendah. Hal ini dapat dilihat salah satunya dari frekuensi kehadiran pengawas pendidikan agama dalam rangka pembinaan, pengawasan, dan pemantauan terhadap penyelenggaraan pendidikan agama di sekolah yang masih golongan rendah. Di sisi lain, materi pembinaan oleh pengawas masih terbatas pada pembinaan administrasi belum menyentuh substansi materi ajar dan metodologi pembelajaran, (d) pemikiran dikotomis antara pendidikan agama dan pendidikan umum mendorong munculnya sikap eksklusif. Sikap ini tampak pada saat berbagai kegiatan keagamaan diselenggarakan terkesan hanya milik guru agama itu sendiri, sehingga guru-guru mata pelajaran non-pendidikan agama kurang responsif.

Salah satu keterbatasan yang dibahas dan menjadi dasar untuk mencari solusi adalah problem sumber daya manusia. Sumber daya manusia berpengaruh penting dalam proses penyelenggaran pendidikan agama agar hasilnya memiliki kualitas di suatu sekolah yang pluralistik. Sumber daya manusia yang dimaksud peneliti pisahkan menjadi tiga komponen, yaitu komponen guru, pengawas pendidikan agama dan pengelola sekolah.

Pertama, problem guru agama. Pendidik agama di SMAN 3 Madiun ini adalah belum semua pendidik agama telah memperoleh sertifikat pendidik. Dari enam orang guru pendidikan agama baru tiga orang yang telah memperoleh sertifikati pendidik sedangkan tiga yang lainnya belum tersertifikasi yaitu guru pendidikan agama Kristen, guru pendidikan agama Buddha, dan guru pendidikan agama Hindu. Dengan kata lain, bahwa ketiga pendidik agama yang belum tersertifikasi tersebut dianggap belum profesional dan akan berdampak pada pembelajaran yang kurang mengikuti perkembang- an psikologi peserta didik, sedangkan tiga guru yang telah memperoleh sertifikat profesi pendidikan agama secara faktual masih perlu ditingkatkan kompetensi profesional khususnya aspek pengembangan profesionalitas secara bekelanjutan, aspek pengembangan diri dan kompetensi kepemimpinan (leadership) juga masih rendah. Rendahnya kompetensi tersebut dapat ditunjukkan dengan rendahnya respon warga sekolah terhadap upaya pembudayaan pengamalan ajaran agama pada komunitas sekolah.

Sebagai sebuah sistem, lembaga pendidikan seperti persekolahan kualitas lulusannya menunjukkan kualitas kerja komponen dalam sistem tersebut. Oleh sebab itu, mutu lulusan sebuah persekolahan identik dengan sekolah tempat dimana lulusan tersebut belajar. Akan tetapi, suatu hal yang perlu diingat dan menjadi keniscayaan, bahwa proses pembelajaran memiliki peran penting dalam menghasilkan mutu lulusan. Sedangkan proses pembelajaran yang bermutu sangat bergantung kepada kondisi kompentensi dan profesionalisme guru. Guru yang kompeten dan profesional akan mampu menjadi substitusi atau melengkapi berbagai kekurangan pada komponen yang lain. Predikat profesional bagi guru diwujudkan dengan adanya kepemilikan sertifikat pendidik agama melalui uji profesi.

Kedua, problem pengawas pendidikan agama. Problem pendidikan agama di sekolah ini adalah kurangnya pengawasan dan pembinaan yang dilakukan pengawas terhadap pengelolaan pendidikan agama yang ada. Pembinaan yang dilakukan oleh pengawas pendidikan agama di sekolah sangat minim dan terbatas pada hal-hal berkaitan teknis, sedangkan yang nonteknis sama sekali belum tersentuh. Kualifikasi pengawas yang menyaratkan berpendidikan Strata-2 sesuai dengan rumpun mata pelajarannya sebagaimana yang tertera pada Pernediknas Nomor 12 Tahun 2007 belum dapat terpenuhi, karena dua orang pengawas baru memiliki kualifikasi Strata-1.

Aspek lain yang ikut mempengaruhi dalam upaya pembinaan adalah komunikasi antara pengawas dengan guru yang kurang 
kondusif. Kehadiran pengawas pendidikan agama di sekolah kurang mendapatkan respon positif dari guru. Penyebabnya adalah ideologi keagamaan yang berbeda antara pengawas dengan guru agama. Konteks komunikasi antara guru dengan pengawas seharusnya lebih menunjukkan kepada peran masing-masing dengan mengedapankan kepentingan bersama dalam meningkatkan mutu pendidikan, sikap eksklusif seperti ini seharusnya dikesampingkan karena sekolah yang ditempati tugas adalah sekolah umum yang memiliki peserta didik dan guru yang beragam keyakinan. Jika kondisi tersebut berlangsung terus maka fungsi supervisi akademik dan manajerial pengawas tidak akan optimal.

Ketiga, problem pengelola pendidikan agama. Pengelola dan sekaligus sebagai penanggung jawab pengelolaan pendidikan agama berada di Kementerian Agama Pusat. Kementeria Agama tingkat Kabupaten memiliki tanggung jawab besar terselenggaranya pendidikan agama yang bermutu di SMAN 3 Madiun. Fakta yang ada tanggung jawab tersebut belum optimal dan belum efektif. Hal ini dibuktikan dengan tidak adanya pengawas pendidikan agama Hindu, Buddha, dan Kristen. Hal ini menunjukkan bahwa tugas pengelola belum optimal. Dampak dari kondisi ini adalah guru pendidikan agama yang belum ada pengawasnya akan melakukan berbagai kegiatan yang lepas dari pengawasan tentu akan menghambat ketercapaian tujuan pendidikan agama di sekolah bahkan sangat dimungkin akan berada di luar kurikulum yang telah ditetapkan.

Kepala Sekolah sebagai pengelola pendidikan di sekolah telah menyadari akan keberagaman etnis maupun agama yang dipeluk para peserta didiknya. Pluralitas tersebut tentu membutuhkan upaya-upaya membangun kehidupan bermasyarakat sekolah bisa harmonis dan tidak muncul gejolak yang disebabkan oleh perbedaan keyakinan. Kepala sekolah sebagai penanggungjawab terselenggaranya pendidikan agama hendaknya menghindari pengambilan kebijakan yang tidak sesuai dengan Peraturan Pemerintah Nomor 55 Tahun 2007 tetang Pen- didikan Agama dan Pendidikan Keagamaan dan Permenag Nomor 16 Tahun 2010 tentang Pengeloaan Pendidikan Agama pada Sekolah. Pemberian ijin tidak masuk sekolah pada setiap hari sabtu kepada sebagian kecil peserta didik penganut agama yang ingin melakukan peribadatan disatu sisi merupakan sikap yang perlu mendapakan apresiasi, di sisi lain kebijakan tersebut dapat menimbulkan kecemburuan sosial diantara peserta didik penganut agama lainnya. Jika kebijakan tersebut diambil seharusnya mempertimbangkan waktu yang dibutuhkan untuk peribadatan, sehingga tidak mengambil waktu selama jam efektif belajar.

Paradigma Pendidikan Agama

\section{Paradigma Keberagamaan Eksklusif}

Memperhatikan uraian proses pembelajaran pendidikan agama di atas dapat disimpulkan bahwa pembelajaran yang dilakukan guru agama di SMAN 3 Madiun masih lebih berorientasi pada dominasi guru ketimbang pemberian keleluasaan atau memberikan kebebasan peserta didik untuk mengembangkan potensi kritik untuk memahami materi agama secara mandiri. Keberpihakan pembelajaran pada guru (teacher certered) semakin membuat tidak percaya diri dan memahami ajaran agama baru pada permukaan belum sampai pada struktur agama yang dalam. Pembelajaran yang berangkat dari teks atau al-kitab (literal-scriptural) yang materinya memerlukan penjelasan secara kontekstual, sedangkan guru tidak berupaya untuk mengkontekstualisasikan maka diyakini hanya akan mengantar peserta didik untuk menerima tanpa melalui proses berfikir yang tepat. Peserta didik di tingkat sekolah menengah secara psikologi menurut Piaget (usia 12 tahun ke atas) perkembangan kognitifnya berada pada tahap operasi fomal (Formal operations). Tahap ini merupakan tahap munculnya kemampuan berfikir logis, berpikir dengan pemikiran teoretis formal berdasarkan proposisi-proposisi dan hipotesis, serta telah dapat mengambil kesimpulan lepas dari apa yang dapat diamati saat itu (Suparno, 2001, p. 88). Sifat pokok 
dari tahap operasi formal ini adalah pemikiran deduktif hipotesis, induktif saintifik, dan abstraktif reflektif. Oleh karena itu, model pembelajaran dan strategi yang digunakan oleh guru pendidikan agama seharusnya mampu memberdayakan daya nalar peserta didik secara optimal untuk memahami ajaran agama yang lebih mendalam. Proses pembelajaran yang bersifat leteralscriptural akan mendorong peserta didik untuk memahami ajaran agama secara rigid, tidak ada upaya untuk memahaminya melalui penalaran yang rasional sehingga mendorong peserta didik memiliki sikap keberagamaan eksklusif. Eklusifisme memiliki pemahaman dan interpretasi terhadap doktrin yang cenderung bersifat kaku (rigid) dan literal.

\section{Paradigma Keberagamaan Inklusif}

Mencermati dokumen rencana pelaksanaan pembelajaran (RPP) terdapat salah satu konsep pendidikan agama Katolik yang sedikit lebih terbuka untuk mempelajari terhadap agama-agama diluar agamanya bagi peserta didik. Akan tetapi, pada tataran implementasi pembelajaran konsep tersebut baru terbatas pada pengenalan terhadap agama-agama lain. Memperhatikan proses pembelajaran pendidikan agama Katolik di SMAN 3 Madiun lebih terbuka dibandingkan dengan pendidikan agama yang lain. Terbuka yang dimaksud adalah guru memberikan sedikit peluang kepada peserta didik untuk memahami materi pembelajaran melalui pengembangan struktur kognitifnya. Hal ini tampak pada penetapan dan penggunaan metode pembelajaran dengan diskusi dengan pendekatan pembelajaran kooperatif (coopertive learning), tetapi di proses pembelajaran, pendekatan dan langkah-langkah tersebut tidak dikawal dengan benar sehingga tidak berfungsi sebagaimana mestinya. Hal ini lebih disebabkan oleh guru pendidikan agamanya kurang menguasai pendekatan dan strategi yang ditetapkan. Jika konsep pembelajaran tersebut diimplementasikan, dengan penggunaan pendekatan dan strategi yang benar maka akan mendorong peserta didik bersikap keberagamaan yang terbuka terahadap ajaran agama lain (inklusif).

Dengan demikian, fenomena keberagamaan inklusif masih menunjukkan adanya kesalahpahaman secara konseptual di dalam memahami ajaran agama. Kesalahapahaman dapat terjadi di kalangan internal pemeluk suatu agama dan juga bisa dari kalangan pemeluk luar agama. Hal ini biasanya ditandai dengan persepsi distorsif (pemutarbalikan fakta) yang memandang semua agama pada dasarnya sama, realitasnya tidak demikian bahkan iklusivisme beranggapan bahwa "tidak menutup kemungkinan ada kebenaran pada agama yang tidak kita anut, dan ada kekeliruan pada agama yang kita anut". Masing-masing agama memiliki karakteristik khusus yang pada titik tertentu terdapat persamaannya, tetapi pada dimensi yang lainnya juga terdapat berbagai perbedaan (Naim, 2008, p. 151). Realitas masyarakat dengan segenap dinamikanya seharusnya menjadi landasan pokok dalam membangun pemahaman agama. Oleh karena itu, sikap keberagamaan iklusif ini hemat penulis masih belum relevan dengan masyarakat Indonesia saat ini khusunya.

Paradigma Budaya Pluralisme Demokratis Emansipatoris

Budaya pluralisme demokratis-emansipatoris yang dimaksud disini adalah merupakan pokok pikiran atau cara pandang yang mendasari suatu pengambilan kebijakan untuk melakukan suatu pembelajaran pen-didikan agama di sekolah yang memiliki keberagamaan penganut agama. Paradigma ini dianggap paling sesuai dengan kondisi SMAN 3 Madiun yang merepresentasikan kondisi masyarakat Indonesia yang pluralistik. Hal ini sejalan dengan prinsip relevansi dan kontekstualitas dalam ilmu pendidikan. Pendidikan harus menyesuaikan dengan kondisi masyarakat dan mampu memenuhi kebutuhan masyarakat (social demand), jika tidak, maka akan ditinggal oleh masyarakat itu sendiri.

Budaya merupakan suatu cara hidup yang berkembang dan dimiliki bersama oleh sebuah kelompok orang dan diwariskan dari 
generasi ke generasi. Dengan demikian, budaya atau kebudayaan adalah suatu pandangan yang menyeluruh dan menyangkut pandangan hidup, sikap dan nilai.

Dalam konteks ke Indonesiaan, masyarakat Indonesia yang beragam etnik, suku, ras, dan agama telah membangun kehidupan bersama dalam ke-"bhinneka"an. Kesan hidup dalam ke-"binneka"-an tersebut telah terjadi sejak awal pergerakan nasional yang ditandai lahirnya "Sumpah Pemuda" tahun 1928 sampai dengan awal masa kemerdekaan. Kebersamaan dalam berbagai perbedaan telah menjadi budaya bangsa Indonesia. Spirit kebersamaan dalam perbedaan tersebut telah tertuang dalam semboyan 'Bhinneka Tunggal Ika'. Oleh karena itu, siapapun yang menjadi bangsa Indonesia agar selalu menghargai dan menghayati akan perbedaan suku bangsa, ras, golongan, dan agama sebagai unsur utama untuk membangun persatuan, bukan menjadikannya sebagai argumentasi terjadinya konflik sosial. Kondisi demikian secara sosiologis merupakan bentuk sosialisasi nilainilai yang terkandung dalam pluralisme.

Pluralisme secara konseptual dapat dipahami sebagai nilai-nilai yang menghargai perbedaaan dan mendorong adanya kerja sama berdasarkan kesetaraan dan mengandung makna dialog guna membangun hubungan antarunsur dengan perbedaan latar belakang, etnis dan agama, maupun budaya. Oleh karena itu, pluralisme bukan hanya merepresentasikan adanya kemajemukan etnis, bahasa, budaya dan agama dalam masyarakat yang berbeda-beda, akan tetapi pluralisme harus memberikan penegasan bahwa dengan segala perbedaan mereka adalah sama di dalam ruang publik (the free public sphere).

Dalam konteks pembelajaran pendidikan agama di kelas, pengahargaan terhadap adanya perbedaan pendapat yang muncul dari peserta didik dalam memahami suatu materi agama seharusnya mendapat respon atau tanggapan yang sama dari guru, walaupun pendapat tersebut datang dari peserta didik yang secara akademis memiliki kemampuan lebih rendah atau inferior secara psikologis dengan yang lain. Peserta didik yang kurang memiliki keberanian rendah diberikan dorongan dengan memberikan apreasiasi agar muncul sikap keberanian untuk mengemukakan pendapat, kendatipun pendapatnya kurang sesuai dengan konsepnya seorang guru agama. Dengan demikian, kondisi pembelajaran pendidikan agama yang seperti ini perlu terus diupayakan menjadi sebuah budaya atau kebiasaan yang harus dilakukan oleh guru-guru agama, agar terbangun komunikasi dua arah antara pendidik dan peserta didik. Keragaman pendapat dari perserta didik menjadikan kelas lebih hidup dan bahkan akan mampu menumbuhkan sikap kebersamaan dan menghindari sikap paksaan untuk menerima satu pendapat dari guru agama. Budaya pluralisme dalam kerangka Negara Republik Indonesia yang menganut sistem pemerintahan demokrasi pancasila hendaknya juga mampu mendorong setiap warga masyarakat untuk berlaku demokratis.

Refomasi bidang politik di Indonesia membawa perubahan besar pada kebijakan pengembangan sektor pendidikan, yang secara umum bertumpu pada dua pandangan baru yakni otonomisasi dan demokratisasi. Undang-Undang Nomor 22 Tahun 1999 tentang Otonomi Daerah telah meletakkan sektor pendidikan sebagai salah satu yang diotonomisasikan dan bersifat keadaerahan.

Otonomisasi pendidikan diarahkan ke sekolah, agar unsur sekolah mulai dari guru hingga kepala sekolah memiliki tanggung jawab bersama dalam peningkatan kualitas hasil belajar peserta didik. Kewenangan pihak sekolah adalah berkaitan dengan perencanaan, proses pembelajaran.

Salah satu isu penting munculnya Undang-Undang Nomor 20 tahun 2003 tentang Sistem Pendidikan Nasional, bahwa pendidikan diselenggarakan secara demokratis dan berkeadilan serta tidak diskriminatif dengan menjunjung tinggi hak asasi manusia, nilai keagamaan, nilai kultural, dan kemajemukan bangsa (pasal. 4.(1)). Demokratisasi merupakan implikasi dari kebijakan pengelolaan di bidang pendidikan pada daerah yang implementasinya ada pada sekolah. 
Perencanaan pengembangan sekolah dari berbagai aspek yang ada di dalamnya diberikan sepenuhnya kepada sekolah dengan melibatkan mitranya yaitu komite sekolah.

Suatu masyarakat dapat dikatakan demokratis apabila di dalamnya telah terimplementasikan prinsip-prinsip demokrasi. Prinsip-prinsip tersebut adalah persamaan, kebebasan dan pluralisme (Ubaidillah, 2006, p. 148). Ciri esensial demokrasi adalah adanya akuntabilitas, partisipasi politik, tidak adanya kekerasan terhadap individu dan adanya pengakuan atas hak-hak individu yang bebas (Mansoor, 2007, p. 112).

Pemikiran demokratisasi dalam penyelenggaraan pendidikan didasarkan pada pertimbangan atas keterlibatan sekolah yang lebih besar dari sebelum keluarnya Undang undang tersebut. Sekolah merupakan miniatur masyarakat yang di dalamnya terdiri atas peserta didik, guru dan tenaga kependidikan yang berlatar belakang berbeda satu sama lain secara agama, kultural maupun emosional. Oleh karenanya, proses pendidikan di sekolah hendaknya secara terus menerus menanamkan nilai-nilai demokrasi dan pluralisme tersebut di atas sembari membangun kesadaran demokratis dan pluralistis. Ortega dalam Zamroni $(2007$, p. 75$)$ menyatakan: "good examples are the results of good education and good education is due to good". Artinya jika menginginkan masyarakat baik maka pendidikannya harus baik.

Pokok pikiran lain yang terkait dengan kebijakan demokratisasi pendidikan adalah keterlibatan peserta didik dalam proses pembelajaran. Keterlibatan yang dimaksud adalah tidak hanya sekedar hadir di tengah proses pembelajaran, akan tetapi para peserta didik diberi kesempatan dalam menentukan kegiatan belajar yang akan mereka lakukan bersama-sama dengan pendidiknya. Keterlibaan peserta didik dalam proses pembelajaran akan menjadi suasana pembelajaran lebih menyenangkan, aspiratif, dan dinamis serta konstruktif.

Emansipasi adalah kata yang berasal dari bahasa Inggris emancipation yang berarti pembebasan dari sebuah kekuasaan atau gerakan untuk memperoleh pengakuan per- samaan kedudukan, derajat serta hak dan kewajiban dalam hukum (Partanto, 1994, p. 145). Emansipasi adalah sebuah gerakan pembebasan dari seorang atau kelompok yang ternegasikan dan termarginalkan dari hegemoni ataupun dominasi kelompok yang berkuasa.

Emansipatorik merupakan sebuah model pendekatan dalam teori ilmu sosial kritis. Kunci dari teori kritis ini terletak pada upaya pembebasan (pencerahan). Menurut teori ini seorang ilmuwan haruslah menyadari posisi dirinya sebagai aktor perubahan sosial. Ilmuwan sosial juga wajib mengkritisi masyarakat, serta mengajak masyarakat untuk kritis.

Harus diakui, pendidikan agama yang dikembangkan sejak dari sekolah dasar (SD) sampai perguruan tinggi selama ini masih lebih besifat verbalistik. Verbalistik menekankan pada aspek indoktrinasi dan penanaman nilai ala kadarnya daripada penumbuhan daya kritis dan pengemabangan intelektualisme peserta didik. Karena sifatnya yang doktriner maka perbuatan salah dianggap sebagai suatu dosa yang diancam neraka bagi yang melakukan. Pendidikan yang semacam ini, di satu sisi memang dapat mendorong anak untuk santun, tunduk atau patuh pada perintah dan bertingkah laku mulia. Namun, disisi lain penumbuhan daya kritis dan pengembangan daya kreativitas berpikir peserta didik akan menjadi terabaikan. Pembelajaran yang verbalistis juga menafikkan potensi perkembangan kognitif peserta didik khususnya yang berada pada usia sekolah menengah (12 tahun ke atas). Pada usia tersebut menurut Piaget, seorang remaja sudah dapat berfikir logis berdasarkan proposisi-proposisi dan hipotesis serta mengambil keputusan dari apa yang dapat diamati pada saat itu. Potensi berfikir demikian ini yang masih belum menjadi perhatian para guru agama karena pembelajaran agama lebih bersifat doktrinis.

Oleh karena itu, di samping peserta didik telah memiliki kebebasan dari berbagai belenggu, potensi berpikir mereka juga harus diberdayakan agar memiliki kesadaran tinggi dan kritis akan kepentingan belajar ajaran 
agama dalam kehidupan bermasyarakat berbangsa dan bernegara. Jika para pendidik menggunakan paradigma demokratis emansipatoris dalam budaya kemajemukan (pluralistik) peserta didiknya maka daya kritis dan kreatif serta sikap kemandirian yang terlepas dari sikap ketergantungan peserta didik kepada guru khususnya akan dimiliki oleh peserta didik.

Dalam konteks masyarakat Indonesia yang pluralistik dan menjadikan Pancasila sebagai falsafah hidup bangsa, teori budaya pluralisme demokratis-emansipatoris merupakan teori budaya alternatif untuk dikembangkan dalam rangka membangun kehidupan yang sejahtera dan mengangkat harkat dan martabat bangsa. Teori ini mengakui keberagaman dan kebebasan serta memberdayakan kelompok yang lemah (grassroot). Jika teori ini diterapkan dalam masyarakat yang agamis, seperti masyarakat Indonesia, maka kelompok grassroot yang inferior diberdayakan tetapi diberi kebebasan untuk menjalankan agamanya secara baik dan benar.

Model paradigma budaya pluralisme demokratis-emansipatoris yang dimaksudkan di sini adalah suatu cara pandang sebagai landasan berpikir dalam melakukan tindakan atau pengambilan suatu keputusan. Tindakan dan atau keputusan tersebut yang berhubungan dengan implementasi pengelolaan dan proses pembelajaran pendidikan agama dalam konteks masyarakat pembelajar (peserta didik) suatu lembaga pendidikan yang memiliki keragaman budaya, ras, golongan, etnis, dan khususnya agama. Karena sifatnya yang ideographik, maka model paradigma ini mungkin kurang kompatibel untuk lembaga pendidikan keagamaan atau sekolah yang peserta didiknya relatif homogen.

\section{Simpulan}

Dari uraian tersebut dapat disimpulkan bahwa pendidikan agama pada sekolah yang memiliki keragaman agama, dan budaya peserta didiknya perlu melakukan perubahan paradigma, karena kondisi masyarakat yang terus berkembang seiring dengan perkembangan berpikirnya masyarakat yang dipengaruhi oleh perkembangan ilmu pengetahuan dan teknologi. Mempertahankan paradigma keberagamaan eksklusif dan keberagamaan inklusif dalam pembelajaran pendidikan agama di sekolah yang pluralistik akan membuat tujuan pendidikan agama sulit dicapai. Model paradigma pendidikan agama yang lebih relevan dengan kondisi sekolah yang pluralistik adalah paradigma budaya pluralisme demokratis-emansipatoris. Model paradigma ini mengakui keberagaman dan kebebasan serta memberdayakan kelompok yang lemah (grassroot). Jika teori ini diterapkan dalam masyarakat yang agamis, seperti masyarakat Indonesia, maka kelompok grassroot yang inferior diberdayakan tetapi diberi kebebasan untuk menjalankan agamanya secara baik dan benar.

Saran

Penelitian ini bertujuan untuk menemukan paradigma pendidikan agama di sekolah yang pluralistik dan mengembangkan ke model paradigma pendidikan agama yang lebih relevan dengan konteks pluralistik dengan segala keterbatasan Produk yang dihasilkan dari penelitian ini baru sampai konseptualisasi paradigma budaya pluralisme demokratis-emansipatoris, peneliti akan ada penelitian lanjutan di tataran implementasinya.

\section{Daftar Pustaka}

Best, J. W. (1997). Reasearch in education, (3rd ed.). Englewood Cliffs. New Jersey: Prentice-Hall, Inc.

Bogdan, R. C. \& Biklen, S. K. (1998). Qualitative research in education: $A n$ introduction to theory and methods. Boston: Allyn and Bacon.

Fakih, M. (2002). Ideologi dalam pendidikan: Sebuah penganta. In W. F. O'neil (Ed.), O. I. Naomi (Trans.), Ideologi-ideologi pendidikan. Yogyakarta: Pustaka Pelajar 
Guba, E. G., \& Lincoln, Y.S. (1985). Effective evaluation. San Fransisco: Jossey-Bass Publishers.

Haikal, M. H. (1990). Sejarah hidup Mubammad. Jakarta: Lentera Antarnusa.

Jaenuri, A. (2002). Ideologi kaum reformis: Melacak pandangan keagamaan mubammadiyah periode awal. A. N. Fuad (Trans.). Surabaya: LPAM.

Kartono, K. (1990). W awasan politik mengenai sistem pendidikan nasional. Bandung: Mandor Maju.

Kneller, G.F. (1993). Politcal ideologies. In George F. Kneller (Ed). Foundations of education. New York: John Wiley and Sons.

Muhadjir, N. (1990). Metodologi penelitian kualitatif pendekatan positivisitik, rasionalistik. Yogyakarta: Rake Sarasin

Muhadjir, N. (2010, Juni). Rekonstruksi sosial untuk kehidupan religious spiritualistik. In Kulliab Umum Pascasarjana Institut Hindu Damma Negeri (IHDN) Denpasar di Hotel Syabid Yogyakarta.

Muhadjir, N. (2011). Metodologi penelitian. Yogyakarta: Rake Sarasin.

Naim, N., \& Sauqi, A. (2008). Pendidikan multikultural konsep dan aplikeasi. Yogyakarta: Ar-Ruzz Media.

Nurmilati, R. A. (2011). Laporan individu Sekolah Menengah (LISM). Yogyakarta: SMAN 3 Madiun.

Peraturan Pemerintah Nomor 32 Tahun 2013 tentang Standar Nasional Pendidikan.

Peraturan Pemerintah Nomor 55 Tahun 2007 tentang Pendidikan Agama dan Pendidikan Keagamaan.
Permendikbud Nomor 64 Tahun 2013 tentang Standar Isi.

Peraturan Menteri Agama Nomor 16 Tahun 2010 tentang Pengelolaan Pendidikan Agama pada Sekolah.

Partanto, P. A., \& Al-Barry. (1994). M.D. Kamus ilmiah populer. Surabaya: Arloka.

Saerozi, M. (2004). Politik pendidikan agama dalam era pluralisme telaah historis atas kebijakan pendidikan agama konvensional di Indonesia. Yogyakarta: Tiara Wacana.

Suparno, P. (2001). Teori perkembangan kognitif Jean Peaget. Yogyakarta. Kanisius.

Tantular, M. (2009). Kakawin sutasoma. D. W. R Mastuti \& H. Bramantyo (Trans.). Jakarta, Komunitas Bambu.

Ubaedillah, A \& Rozak, A.(2006). Demokrasi, hak asasi manusia dan masyarakat madani. Jakarta: ICCE Syarif Hidayatullah.

Undang-Undang Nomor 20 Tahun 2003 Tentang Sistem Pendidikan Nasional. Bandung; Fokusmedia.

Undang-Undang Nomor 14 Tahun 2005 Tentang Guru dan Dosen.

Undang-Undang Nomor. 22 Tahun 1999 Tentang Otonomi Daerah.

Waldman, M.R. (1985). Primitive mind/modern mind: New approaches to an old problem applied to Islam. In R. C. Martin (Ed.). Approachs to Islam in religious studies. USA: University of Arizona Press.

Wilson, S. (1995). The use of ethnographic techniques in educational research. New York Academic Press.

Zamroni. (1992). Pengantar pengembangan teori sosial. Yogyakarta: Tiara Wacana. 